\title{
Functional Mathematics Education: A Tool for Developing Entrepreneurship for Sustainable Self Reliance of Nigerian Graduates
}

\author{
Odiri E. Onoshakpokaiye ${ }^{1 *}$ (D)
}

${ }^{1}$ Institute of Education, Delta State University, Abraka, NIGERIA

*Corresponding Author: onos68@yahoo.ca

Citation: Onoshakpokaiye, O. E. (2021). Functional Mathematics Education: A Tool for Developing Entrepreneurship for Sustainable Self Reliance of Nigerian Graduates. Contemporary Mathematics and Science Education, 2(1), ep21003. https://doi.org/10.30935/conmaths/9678

\begin{abstract}
The responsibility of every nation to her citizens is by providing a job for them. Many Nigerian graduates and school leavers are on the street in search of job as a result of lack of employment opportunities, this has become a very serious problems in the nation today. There is the need to inculcate in the students entrepreneurial skills through functional mathematics to enable them to be self-employed. In the Nigeria system of education much emphasis has not been placed on functional mathematics, not knowing that it is the tools for entrepreneurship. Most of the school leavers and graduates from Nigerian schools are unemployed as result of insufficient job opportunity. There is need for the government to lay more emphasis on the teaching of mathematics to make it more functional so that the students can acquire mathematics skills that will assist them to be an entrepreneur and become self-reliance. Nigeria as a nation need functional mathematics and entrepreneurship skills in their various schools to enable her citizens acquire practical skills for sustainable self-reliance. The Paper examined the importance of mathematics, entrepreneurship, functional mathematics and entrepreneurship and ways to develop entrepreneurship for sustainable self-reliance. Some recommendations were also made.
\end{abstract}

Keywords: functional mathematics, entrepreneurship, self-reliance, Nigerian graduates

Received: 20 Aug. 2020 • Accepted: 24 Nov. 2020

\section{INTRODUCTION}

The responsibilities of every government are to provide employment for her citizens. Experience has shown that Nigeria government alone cannot provide jobs to all the secondary school leavers and graduates from all the tertiary institutions Elebe (2011). According to Odumosu and Olusesan (2016), "one of the problems facing Nigeria and many other developing nations has been that of unemployment. Majority of college leavers and university graduates are jobless. This perhaps may be because of over dependence on government jobs or white-collar jobs." Onuegbu (2006), stated that students population increase in geometric progression while the growth of job opportunities have been in arithmetic progression and that many of the Nigerian graduates are unemployed and are all over the country in search of employment which cannot be found anywhere. It shows that Nigeria nation is in great danger and also facing economic problems which will eventually result to high rate of unemployment, poverty, crime and hunger.

To end to these foreseeing problems, there is need for the nation to have a functional mathematics education that will serve as a tool for entrepreneurship for the students to acquire skills so that when they graduate, they can be self-employed. When the students graduate, the skills they acquire can be used to establish small scale business to sustain themselves. Igweh (2005) stated that when the business begins to yield profit within a short time, such business is referred to as successful and this may not always be true because such investment may fail and that is why business is referred to risk taking. For that reason, people should plan well not to fail but to succeed in their business Igweh (2005). With the above reason it becomes very necessary for students to acquire some basic knowledge and practical skills on entrepreneurship so as to succeed in their business when they graduate, and this is where functional mathematics education and entrepreneurship educations are needed. Since no one can do without mathematics skills in life and every business, these two must go together. With the enabling environment, entrepreneurship education and function education will enlighten and equips the students with the modalities and mathematics skills needed for the operation and managing business. By so doing the Nigerian graduates are empowered for sustainable self-reliance, wealth creation and self-employment, thereby creating jobs for themselves and other Nigerian citizens.

Integration of functional mathematics education in the nation education system from secondary level to tertiary level will develop entrepreneurship education for sustainable self-reliance among Nigeria 
graduates. According to national policy on education, mathematics is made compulsory from primary to secondary levels and it is one of the requirements for any candidate to be admitted into the Nigerian university. Mathematics is one of the few subjects which are taught in most countries to all students throughout many years of schooling and it is an integral to everything about life (Agwagah,2005). Mathematics develop critical thinking. The important aim in education is to develop students' critical thinking. According to Agwagah (2005) “Critical thinking implies very important information processing upon which future knowledge depends. One of the core subjects in the school curricular, for achieving development in critical thinking is mathematics".

\section{Importance of Mathematics}

Ezenweani (2006) described mathematics as "the branch of knowledge that seeks to improve on human perception of himself and his immediate environment by using clear, logical precise and exact thinking processes". Mathematics is an integral part of human life. Man use it either directly or indirectly in our everyday activities (Onoshakpokaiye, 2011). Roohi (2012) define Mathematics as a branch of science which involves calculation, computation, solving of problems and also deals with numbers and their operations. Roohi (2012) went further to say that Mathematics is the study of quantity, space and structure and it also reveal to us that hidden patterns which enables us to understand the world around us. The importance of Mathematics to our everyday living cannot be overemphasized. There is no one on earth that can do without mathematics, it has become part of our life and everyday living. It has become an indispensable tool for the progress and development of the entire world today (Roohi, 2012). The significant role mathematics play has taken over almost every aspect of human life ranging from everyday activities like buying food, organizing, maintenance of schedules for aircraft and so on (Amarjeet and Malik, 2016). Odumosu et al. (2016) stated that "Mathematics is more than just the science of numbers taught by teachers in schools and either enjoyed or feared by many students." The significant role mathematics play in every human life towards the progress of any society is innumerable.

The use of mathematics in our everyday life and in the workplace cannot be overestimated. Everyone makes purchasing decision, choosing health insurance understanding the world around us and this call for the use of mathematics (Roohi, 2012). Most of all the careers based their foundation on Mathematical knowledge and skills most especially science courses and other courses that deals with calculation. According to Amarjeet et al. (2016), "Mathematics plays a very important role in organizing and communicating information. It provides a powerful, concise and fairly unambiguous way in this field. Mathematics serves as a means for explaining and predicting various aspects of the physical universe. It is a problem-solving activity supported by a vast body of knowledge." Competence in mathematics unlock the doors to every productive future while lack of mathematics competence closes the doors. There is no subject where mathematics is not involved. According to Amarjeet et al. (2016), "study of Mathematics has attained the great distinction of involvement with every subject of science, management, commerce and economics. The study of Mathematics is also important in the teaching of entrepreneurship, marketing and salesmanship.” Roohi (2012) stated that "Mathematics occupies a crucial and unique role in the human societies and represents a strategic key in the development of the whole mankind. The knowledge and mathematics skills are indispensable to everyone, no one can actually function effectively without mathematics." All-mental abilities of the child are developed through problem solving in mathematics. Mathematics makes the man to be more calculating so that he/she can make use of the time, money, thought and so on effectively (Roohi, 2012). The functional mathematics develops in us strong will power that develop our brain for discovery and invention, make us to be self-dependent and contribute to the development of our society.

\section{Entrepreneurship Education}

Idu (2018), define an entrepreneur "as a person who, after changing a dream into a vision plunges headlong in an attempt to exploit a sociopolitical and economic landscape of opportunities with unknown amount of risks." Entrepreneur is person who initiates, organizes, manages business or enterprise and also bears the risks that are involve in the business. According to Omogiate-Iwelu (2016) cited in Idu (2018), entrepreneur is the one who has the vision or the ideas and how these ideas can be useful for the good of everyone. The true entrepreneur is someone who has a dream or vision, take action and ensure that it materializes. One thing about the entrepreneur is that he/she is self-employ, bear risks, and has positive innovation and also an employer of labour (Bushnell, 2012; Idu, 2018).

An entrepreneur organizes, manage, bears the risks of the enterprise or business, an agent of change and makes profit. Entrepreneur is someone who has the ability to develop a new venture in business so as to make profit, which often involves financial risks (Ogbe and Omenka, 2019; Quirk, 2003). Entrepreneur can be defined as someone who initiate a business, organize it, bear the risks that are involves and also the owner of the business for the sole purpose of maximizing profits. An entrepreneur is someone who sets up a business or venture for the purpose of maximizing profit at the end. Entrepreneurs create jobs, make jobs available for other citizens without waiting for government, assisting the government in creating more employment. They employ themselves and bears the risks of the business. As their business progresses, they create more jobs thereby reducing unemployment, crimes, poverty and help feeding families of other citizens. Entrepreneurs generates wealth for the nation and improve national incomes. According to Ogbe et al. (2019), an entrepreneur is a person who has developed certain skills, attitudes and behavior that enables him/her establish a business or venture, thereby creating employment for himself/herself and others. The entrepreneurs innovate and they are capable of developing new products, new technologies, and services which they adapt to the existing technologies.

Igweh (2005), defines "entrepreneurship as the ability to set up an enterprise as different from being employed. This ability involved the acquisition of skills, ideas and managerial competences necessary for self-employment." Iyekekpolor (2006), defines entrepreneurship as the initiator of a new business or an organization. It is an act of showcasing ones skills in starting a business with the main purpose of profit making, and that, an entrepreneur perceives opportunities which others do not. He is always searching for change, responding to it and exploiting viable business opportunities. According to Inegbenebor (2006) in Ogbe et al. (2019) "Entrepreneurship raises the level of productivity in the economy by harnessing and utilizing resources efficiently." Entrepreneurship education provides the necessary skills and training experiences that are needed to develop or initiate and own 
a business (Ovie 2011, Ogbe, el al, 2019). Idu (2018), stated that entrepreneurship is the art or science of being an entrepreneur or someone who undertakes innovations, finance a business in an attempt to transform the innovations into economic goods. It is a process of exploiting the existing opportunities or that are created in the environment through innovation in order to create value. According to Ezema (2000) in Ogbe, et al (2019, entrepreneurship education is the education given to a student to enable him/her to acquire or develop the skills needed for managing a business venture. The entrepreneurship education equips the students to take financial risk of venturing into business, make use of the available materials and human resources to establish their own business. It is of great importance in the sense that it prepares both the secondary school leavers and graduates with the needed entrepreneurial skills, make use of these skills to start or establish their personal business to become selfemployed and also be an employer of labour.

Many schools are now seeing the importance of entrepreneurship education, they are trying to key into it. Entrepreneurship education is now an important issue in the life of Nigerians and institutions of learning. In Nigerian schools right from secondary level to tertiary institutions are now seeing the need for the inclusion of the entrepreneurship education in the school's curriculum (Ogbe et al., 2019; Rinji, 2013). Acquiring entrepreneurship skills is of great help to both business and non-business students at all levels of education since it develops them to be self-employed. It is also of immense help to the teachers because it will develop them socially and economically."

\section{FUNCTIONAL MATHEMATICS AND ENTREPRENEURSHIP}

Mathematics need to be taught as a functional subject. It should not be taught just as an ordinary subject, the practical aspect of it should be emphasized so as to develop the mathematical skills in the students to make them to be self-reliance thereby assisting them to acquire entrepreneurship skills to establish their own business and become selfemployed. Functional Mathematics skills are practical skills that the students acquired in mathematics to enable them work confidently, effectively and self-dependent in life. Functional skills entail knowing when and how the acquired knowledge and skills are used in real-life situations. The students can develop these skills through adapting and applying what they have learned in school to suit different situations that they may face in life (Functional Skills Support Programme (FSSP, 2008). Functional mathematics skills are of great significant because it develops the students to be self-reliance, enables them to manage in a different circumstance, develop employable skills and give a solid foundation for further training or learning. Functional Mathematics skills entails identifying problems or challenges in mathematics, selecting from the knowledge that we have acquired and then applying the knowledge to find effective solutions. Students who are mathematically skilled apply the mathematics they know to solve problems they encounter when the need arises in their life and place of work. Some of the goals of Nigeria education as stated in the national policy on education, it stresses the "development of appropriate skills, mental, physical and social abilities and competences to empower the individual to live in and contribute positively to the society (FRN, 2013)".
"Acquisition of functional skills and competences necessary for selfreliance provide the child with diverse basic knowledge and skills for entrepreneurship and educational advancement. Give training and impact the necessary skills to individual for self-reliance economically (FRN, 2013)". With the situation of things in Nigeria, we can infer that Nigeria education system has failed in this area when compared to the education goals. Most of the secondary school leavers and graduates from tertiary institutions are on the street looking for employment that does not exist. These goals can only be achieved through functional mathematics. To acquire appropriate skills, mental, physical, social abilities and competences to empower and contribute meaningfully to the development of Nigeria, there must be a functional mathematics because these are the quality or contributions of functional mathematics to the society.

Functional Mathematics Education prepares students to be selfreliance and self-employed. Most of the school leavers and university graduates are unemployment due to how the subject is being taught in most of Nigeria schools, the practical skills aspect is not being taught in the schools (Nwachukwu, 2009; Ogbe et al., 2019; Okori, 2015). Due to lack of functional mathematics, most of the secondary school students and graduates are without practical skills and experience (Ogbe et al. 2019). These problems need to be handled very well in the area of teaching mathematics so as to produce citizens with sufficient functional mathematics skills or practical skills for self-reliance, selfdependent and contribute to the development of society. Entrepreneurial skills according to Adeyemo (2009), are the basic skills needed by a student to assist him/her develop, start, and finance his/her business or enterprise. Inculcating mathematical skills in the students enables them on graduation to be self-dependent, useful citizens and self-employment.

According to Roohi (2012), the main aim of education is to assist the children earn their living and make them to be self-dependent. She recommended that to achieve this aim, mathematics remains the very subject or the most important subject than any other. Mathematics assist us in preparing students for science and technology, technical and other mathematics related vocations like the banking, architecture, accountancy, engineering, business and so on. Even working in our offices needs mathematical knowledge therefore no aspect of our life is left out when it comes to the use of mathematics.

The immense contributions of functional mathematics to the modern society are too numerous to mention. According to Roohi (2012), "mathematics provides the vital underpinning of the knowledge of economy. It is essential in the physical sciences, technology, business, financial services and many areas of ICT. Mathematics forms the basis of most scientific and industrial research and development." Many of the complex systems. Structures, sophisticated technological systems in our modern world today came into being as result of functional mathematics and can only be interpreted and understood with aid of mathematics and it also depends on mathematical languages or symbols (Roohi, 2012). Roohi (2012) stated that "The 'functional' aspect of mathematics stems from its importance as the language of Science,

Technology and Engineering, and its role in their development without mathematics, there can be neither science nor engineering."

Mathematics has been referred to as the basic foundation of almost all vocations and everyone apply it in their daily living knowing or unknowing. Due to the importance nature of this subject" mathematics" as a basic foundation for successful learning and living, that is why it 
was made a compulsory subject in the Nigeria system of education right the from primary schools' level to tertiary institutions. Functional mathematics inculcate and develop entrepreneurship skills in the students. Ogbe et al. (2019) suggested that functional mathematics education should equip the students with practical mathematics skills and knowledge needed for them to effectively function and then contribute to the overall progress of the society or nation. Abdu (2005) sees functional mathematics education as the all-round training of the students that makes him/ her to be useful to themselves, their community they live in and the entire nation. Functional mathematics education is that education that works, relevant, prepares the student to face his/her social goals, economic realities and can be applied to solve their immediate problems with the prerequisite skills and knowledge to function effectively in the society he/she belongs to and face future challenges positively. It brings about social and meaningful development of a nation.

For mathematics education to be functional it must be relevant to the needs of the society, promote citizens welfares. economic growth, science and technological advances and not training of high-level manpower only but they should contribute to the development of the nation as a whole, because education is the foundation on which every other sector is built upon (Ogbe et al., 2019). During Mathematics class emphasis should be on entrepreneurship, focus should be on developing innovation, risk taking, imagination, problem solving and decisionmaking skills (Idu, 2018; Omogiate-Iwelu, 2016). Mathematics is a subject that is in every profession due to its importance. It is a subject that students cannot do without if they are to be self-reliance, selfemployed and be an employer of labour. Mathematics improves the standards of living, creative and reasoning skills of everyone. Mathematics knowledge and skills assist the entrepreneur to understand market strategies, evaluates his/her target consumers, analyze data and how the business can improve (Omogiate-Iwelu, 2016).

According to Idu (2018), "entrepreneurship is a means of reinventing the world through science and mathematics education Functions of entrepreneurship include self-employment, job creation, income generation and empowerment, and poverty alleviation." The Scientific processes and the entrepreneurial processes should be compared when teaching mathematics so that these two can be integrated for easy understanding and for the students to be able to apply the skills. According to Idu (2018), "The scientific method invariably starts with identification of problem. Mathematics tends to build a wide range of interdisciplinary skills that can prepare studentsentrepreneurs adequately for the future." Mathematics teaching should be approach in practical ways, it should be practically oriented to ensure mathematics skills are inculcated in the students, to acquire entrepreneurial skills that will assist them recognize or exploit the available opportunity to be an entrepreneur. Idu (2018) stated that "Mathematics teachers must as a matter of necessity include in their entrepreneurial activities in the class to sustainable practical skills, excursions, industrial attachments and projects-oriented activities." He went further to say that "Mathematics uses the method of systems thinking. System thinking is the process of understanding how things influence one another within a whole."

Systems thinking is a problem-solving approach, viewing problems or challenges as parts of an overall system instead of reacting to specific part, outcomes and potentially contributing to further development of unintended consequences (Ackoff, 2010; Idu, 2018). The contribution of mathematics to the growth of modern civilizations are overwhelming compare to any other subjects, it is part of man's life. (Idu, 2013) cited in Idu (2018) stated that "the uniqueness of mathematics emanates from the fact that it assumes the culture of all people and tribes. Mathematics has indeed been a beacon of light to all the sciences and entrepreneurship skills acquisition". According to Odumosu et al. (2016) "Nigeria, like every other nation in the world, depends upon mathematics as one of the most important subjects that could help the nation meet her objectives for science and technological advancement towards the realization of the vision 2020," Mathematics skills enables the entrepreneur to work out the cost of labour and cost of production before he/she can start any business.

Every modern industry or business has a separate Research and Development department where research is being carried out for quality control, maintenance of machine and development of machines or equipment and other functions. This department cannot succeed without the application of mathematics (Amarjeet et al., 2016). The Mathematical knowledge and skills are required by every human to live a successful life. To live a social life, to do our business and to work together as a team the mathematics knowledge and skills are required. Mathematics involves Problem solving, development of mental, critical thinking and reasoning ability. It develops our brain and make our brain to be active through problem solving.

\section{WAYS TO DEVELOP ENTREPRENEURSHIP FOR SUSTAINABLE SELF RELIANCE OF NIGERIAN GRADUATES}

To develop entrepreneurship for sustainable self-reliance of the Nigerian graduates, the following ways are necessary:

Employment of Professionally Qualified and Competent Mathematics Teachers/Lecturers

Professionally qualified and competent mathematics teachers/lecturer who can teach mathematics as a functional subject should be engaged. The mathematics teachers should be able to use the appropriate teaching skills to inculcate the entrepreneurial skills in the students so that when they graduate, they will be able to apply the mathematics skills, to set up their own business and become selfdependent.

Seminars and Workshops for the Students and Mathematics Teachers/Lecturers

Seminars and workshops should be organized for the mathematics teachers to equip them with the latest or the current trend of mathematics teaching or how mathematics is being taught using the latest technology. Also, Seminars and workshops should be organized for the students to train them on how to use these skills they acquired through mathematics and this can be done by inviting a successful entrepreneur to deliver lecture on functional mathematics and entrepreneurship.

Restructuring of mathematics curriculum: The mathematics Curriculum must be restructured to make it more functional. In doing this, topics that will develop the mathematical skills of the students should be included to make the subject to be more relevant and enable the students acquire mathematics skills that will help them to be self- 
dependent or self-reliance and contribute to the development of Nigeria as a nation.

Teaching method: The mathematics teachers should use appropriate teaching method to make it more practical. He/she should use teaching method such as field trips, demonstration and inquiry method when teaching entrepreneurship education so that the lesson can be effective.

\section{CONCLUSION}

Functional mathematics and Entrepreneurship are very important in educational system, it has the potential of equipping the students with the required skills that can assist or develop them to be self-reliant, creates job for themselves and become employer of labour. School leavers and most especially university graduates should be taught on how to apply the acquired skills to become self-reliance and set up business or venture that can generates income for them instead of depending on the government for an employment.

The mathematics teachers should ensure mathematics is taught as a functional subject and also put in their best to inculcate this functional mathematics and entrepreneurial skills into the students to enable them use it to establish their own business to be gainfully employed, engage other citizens and contribute to the growth of the nation.

\section{RECOMMENDATIONS}

The federal and state Government should improve on the conditions of service of the mathematics teachers/lecturers to encourage them so as to make mathematics teaching to be more functional for the students to acquire mathematics skills for entrepreneurship.

The students should be encouraged to study mathematics, science subjects, science and technology and other courses that will enable them to acquire practical skills for sustainable self-reliance and also become employer of labour.

Curriculum of Mathematics should be reviewed and restructured to make it more practical oriented to acquire entrepreneurship skills.

To make the teaching of mathematics to be more functional, both federal and state Governments should ensure they organize workshops for the mathematics' teachers and also send them out for in-service training to be able meet up or adapt to the current trend of mathematics teaching.

The functional mathematics skills, their rules and principles should be well taught in schools to assist the students in the area of problem solving and effective communication for them to acquire entrepreneurial skills.

Students should be exposed to the necessary functional mathematics skills so as to awake them to develop innovative ideas or skills that will assist them start their own personal business.

The school system should take entrepreneurship as their uppermost priority in the school, whether business or non-business students to reduce unemployment.

The teachers should expose the students to practical skills outside the school system by organizing field trips for them, this will enable them to get first-hand information and seeing how things works with their eyes.

\section{REFERENCES}

Abdu, A. (2005). Functional secondary education for self-reliance: The way forward. Multidisciplinary journal of research development, 5(1), 101-108.

Ackoff, R. L. (2010). System thinking for Curious Managers. USA, Triarchy Press.

Adeyemo, S. A. (2009). Understanding and acquisition of entrepreneurial skill: A Pedagogical re-orientation of classroom teacher in science education. Journal of Turkish science education, 6(3), 57-65.

Agwagah, U. N. V. (2005). Teaching mathematics for critical thinking, essential skill for effective living. The Journals of Mathematics Association of Nigeria, Abacus, 30(1), 38-45.

Amarjeet, M., \& Malik, A. K. (2016). The role of Mathematics in Entrepreneurship. International Transactions in Mathematical Sciences and Computers, 9(1-2), 92-96.

Bushnell, N. (2012). Entrepreneurship. Retrieved from www.ThinkExist.com

Elebe, M. I. (2011). Integrating entrepreneurship Education in Technical and vocational Education (VTE) Curriculum: A toot for sustainable self-reliance for Nigerian youth. Journal of Research in Education, 2(1), 55-60.

Ezema, P. C (2000). Inculcation of entrepreneurial skill in students: A challenges to home Economics Teachers [Paper presentation]. 5th National Conference of women in college of education, F.C.E Akoka Lagos, 23-24 October, 2000.

Ezenweani, U. L. (2006). Mathematics and Classroom Teaching. Abraka, Delsu Press.

Federal Republic of Nigeria. (2013). National Policy on Education (6th ed.), Lagos: NERDC Press.

Functional Skills Support Programme (FSSP). (2008). Resources to support the pilot of functional skills teaching and learning functional mathematics. https://www.ncetm.org.uk

Idu, E. U. (2013). Effects of Computer Assisted Instruction on the Achievements of Pre-NCE Students in Geometry (Unpublished Ph.D Project), Department of Science Education, UNN.

Idu, E. U. (2018). The Role of Mathematics in Enhancing Entrepreneurship Development in Nigeria. International Journal of Science and Research (IJSR), 7(1), 1736-1739.

Igweh, A. U. (2005). Entrepreneurship Education in Technology Programmes: A panacea for sustainable youth empowerment. Proceedings of the $1^{\text {st }}$ annual National Conference of Nigerian Association of Teachers of Technology (NATT). Lagos: Rothemed International Limited.

Iyekekpolor, A. C. (2006). Problems of Entrepreneurship in Business Education sector of the economy Multidisciplinary. Journal of Research Development (NARD), 7(7), 68-70. 
Odumosu, M. O., \& Olusesan, E. G. (2016). Acquisition towards the Realization of Vision 20:2020. International Journal for CrossDisciplinary Subjects in Education (IJCDSE), 7(2), 2768-2773. https://doi.org/10.20533/ijcdse.2042.6364.2016.0377

Ogbe, A. O., \& Omenka, J. E. (2019). Science and mathematics education as tools for developing entrepreneurship skills among secondary school students in cross river state, Nigeria. Global Journal of Educational Research, 18, 35-45. https://doi.org/10.4314/ gjedr.v18i1.5

Okori, A. O. (2015). Science education development in Nigeria (Seminar paper presentation), University of Agriculture, Makurdi, Benue State.

Omogiate-Iwelu, L. (2016). Relevance of Mathematics in an Emerging Economy.

Onoshakpokaiye, E. O. (2011). The influence of teachers' attitude on students' learning of mathematics in Nigeria secondary schools. Journal of Research in Education, 2(1),15-21.
Onuegbu, C. I. (2006). Repositioning, Vocational and Technical Skills Acquisition: A tool for Economic Advancement. Multidisciplinary Journal of Research Development (NARD), 7(7), 20-26.

Ovie, R. A. (2011). The Relevance of STMB Education in the development of skills and Women employment. Academic scholarship Journal 3(i), 179-183.

Quirk, R. (2003). Longman Dictionary of Contemporary English. England Pearson Education Limited.

Rinji, D. G. (2013). The use of information and communication technologies (ICTS) for Entrepreneurship education for youth empowerment" in Nigeria. The International Journal of Education studies(IJES), 1(3), July, 2013.

Roohi, F. (2012). Role of Mathematics in the Development of Society. National Meet on Celebration of National Year of Mathematics-2012; organized by NCERT, New Delhi. 